\title{
DIFFUSION OF EFFECTIVE BEHAVIORAL INTERVENTIONS AND HISPANIC/LATINO POPULATIONS
}

\author{
JoAna M. Stallworth, Jonny F. Andía, Rashad Burgess, \\ Maria E. Alvarez, and Charles Collins
}

\begin{abstract}
The national HIV/AIDS prevention program, the Diffusion of Effective Behavioral Interventions (DEBI), is described in the context of addressing Hispanics/Latinos at risk for HIV/AIDS in the United States and Puerto Rico. The eight-step DEBI model is referenced in terms of the interventions and Division of HIV/AIDS Prevention/Capacity Building Branch (DHAP/CBB) Latino Diffusion Team activities. A summary of activities and examples addressing diffusion needs for the diverse Hispanic/Latino populations is discussed. Challenges and successes in diffusion and partner collaborations are also presented, with comment on future directions such as translations and trainings to serve the needs of the Hispanic/Latino-serving communitybased organizations and their communities.
\end{abstract}

The Diffusion of Effective Behavioral Interventions (DEBI) Project, now in its $7^{\text {th }}$ year, is a national HIV prevention program of the Division of HIV/AIDS Prevention of the Centers for Disease Control and Prevention (CDC) with the goal to develop and coordinate intervention resources, training, technical assistance, and other capacity-building activities on evidence-based, behavioral interventions to health departments, community-based organizations (CBOs), and health care providers (Collins, Harshbarger, Sawyer, \& Hamdallah, 2006). Through the partnerships with training centers, capacity-building assistance providers, and health departments, the DEBI Project aims to reduce HIV, hepatitis, and sexually transmitted diseases (STDs). As of July 2009, there are 23 DEBI interventions with a growing inventory. (See Table 1 for a partial list of DEBI interventions and key descriptors.)

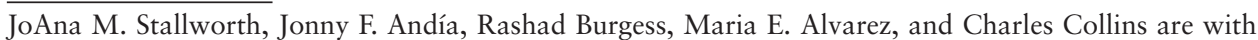
the Capacity Building Branch, Division of HIV/AIDS Prevention (CDC), Centers for Disease Control and Prevention, Atlanta, GA.

The authors acknowledge Gerardo Pacheco, Lisette Arredondo, Jessica Watson, and Dr. Aisha Gilliam for their assistance with this manuscript.

They further acknowledge the Latino Diffusion Team, whose members include Jaime Altamirano, Angie Alvarado-Cordero, Maria E. Alvarez, Jorge Alvarez, Maria Ayala-Perales, Nelson Colon-Cartagena, Julio Dicent Taillepierre, Monique Eadon, Jasmin Minaya, Angel Ortiz-Ricard, and Sandra Serrano-Alicea.

The findings and conclusions in this article are those of the authors and do not necessarily represent the views of the CDC.

Address correspondence to JoAna M. Stallworth, Ph.D., M.P.H, Capacity Building Branch, Division of HIV/AIDS Prevention, NCHHSTP, 1600 Clifton Road NE, Mailstop E-40, Atlanta, GA 30333; e-mail: jstallworth@cdc.gov 
As DEBI began to be diffused, increasingly the question "What is available for Hispanics/Latinos?” was asked. To begin to strategically respond to this request, other questions had to be answered: What risk behaviors are in question? Which Hispanics/Latinos are at risk? Where are they geographically located? What level of acculturation are the populations? What language should be used? Furthermore, the question of agency capacity to successfully implement an evidence-based behavioral intervention had to be addressed (Collins, Phields, \& Duncan, 2007).

The DEBI Project entails reaching the residents of Puerto Rico, where Spanish is the predominant language. Though many Hispanics/Latinos residing in the mainland United States at risk for HIV/AIDS may be English speakers, there also exist sizable monolingual Spanish-speaking populations at risk for HIV/AIDS (e.g., Los Angeles, New York City, and Florida). Materials available to disseminate within these areas need to be in both English and Spanish. In addition, requests for Spanish-language DEBI materials were made for all interventions being implemented (Centers for Disease Control and Prevention, 2006, 2007a).

Through the Latino Diffusion Team (LDT), an internal workgroup in the Capacity Building Branch in collaboration with the Prevention Program Branch, concentrated efforts have been made in moving the DEBI products in a direction of cultural and linguistic appropriateness for the needs of the diverse Latino populations disproportionately affected by HIV. Activities of the LDT entail internal collaboration across branches and divisions, as well as external collaboration with capacitybuilding providers, community agencies, and health departments for review and development of materials as part of the evidence-based interventions of the DEBI Project.

In this article, we describe some of the DEBI Project and LDT activities that seek to address diffusion and implementation needs for the diverse Hispanic/Latino populations. Some challenges and successes in diffusion and partner collaborations are also presented. We end with future directions, such as additional translations, adaptations, and trainings, to serve the identified needs of the HIV Prevention Hispanic/Latino-serving agencies and their communities.

\section{METHODS}

Current diffusion of evidence-based interventions to Hispanic/Latino populations follows the eight-step process of the DEBI Project: (a) planning with a vision, (b) developing a health marketing strategy, (c) developing policy support and incentives, (e) developing an intervention program package design, (f) training, (g) capacitybuilding and technical assistance to community-based organizations and health departments that are implementing programs, (h) providing quality assurance, and (i) evaluating program processes and client outcomes. Each of these has been previously described by Collins et al. (2006).

Using this eight-step framework and planning for dissemination of interventions to Hispanic/Latino populations, the LDT, often in collaboration with the original researchers, reviewed and fine-tuned intervention packages, including materials and trainings, for cultural and linguistic appropriateness.

Based on an understanding of the needs of the communities through a formal community assessment, the service provider will have the needed information to create a better match of selecting the evidence-based intervention for the community. In addition to this basic formative assessment of potential end users, the capacity of the 
implementing agency or agencies is assessed (e.g., support from key stakeholders, appropriate staff, access to target population, and available facilities).

\section{DEBIS IN DISSEMINATION AND IN DEVELOPMENT}

There are now 23 DEBI interventions being disseminated and another four in the packaging stages with the following HIV risk categories and populations targeted: injection drug users (IDUs), men who have sex with men (MSM), heterosexual women, heterosexual couples, youth at risk, and incarcerated men. Some of these interventions were designed to be culturally specific for African Americans and Hispanics/Latinos. Three interventions, Cuídate, Modelo de Intervencion Psicomedica (MIP), and Salud, Educacion, Prevencion y Autocuidado (SEPA) were designed to be culturally specific for Hispanics/Latinos. The Cuidate intervention targets the HIV transmission risk behaviors of heterosexual Hispanic/Latino adolescents while SEPA targets heterosexual adult Hispanic women/Latinas, and MIP targets Hispanic/Latino IDUs. Other evidence-based interventions targeting various HIV transmission risk behaviors that have been found to be efficacious for multiple ethnicities, including Hispanics/Latinos, are Safety Counts; Community Promise; Video Opportunities for Innovative Condom Education and Safer Sex (VOICES/VOCES); Partnership for Health; Holistic Health Recovery Program (HHRP); and Together Learning Choices (TLC). For a brief description of each intervention, see Table 1.

\section{ADAPTED DEBIS}

As the first intervention disseminated through the DEBI project, VOICES/ VOCES was also one of the first interventions to be adapted (Harshbarger, Simmons, Coelho, Sloop \& Collins, 2006). VOICES/VOCES is a video-based HIV/STD prevention intervention designed to increase condom use and improve condomnegotiation skills among STD clinic patients. Though VOICES/VOCES originally included videos that targeted both heterosexual African American and Hispanic/Latinos, community feedback indicated that the videos required updates. The original video targeting Hispanic/Latino populations, Por que Sí, included one sentence in English and one sentence in Spanish so that both monolingual Spanish speakers and monolingual English speakers could understand the video content. However, there were numerous complaints that the mixture of Spanish and English dialogue was culturally insensitive. Subsequently, new videos were produced, including a Spanish language version with no English dialogue.

Though not originally researched with Hispanics/Latinos, the following interventions are now being disseminated and packaged with Hispanic/Latino populations: Sisters Informing Sisters on Topics About AIDS (SISTA); Real AIDS Prevention Project (RAPP); Many Men, Many Voices (3MV), and Adult Identity Mentoring (AIM). SISTA, originally developed with African American women, has been adapted by agencies serving Hispanic women/Latinas. Because of the overwhelming request to implement SISTA with Hispanic women/Latinas, an adaptation guide, SISTA for Latinas, was developed in collaboration with both Hispanic/Latino and African American social science volunteers of the Behavioral and Social Science Volunteers (BSSV) program, administrated through the American Psychological Association, capacity-building assistance (CBA) providers, community volunteers, and CDC staff (American Psychological Association, 2008). The adaptation guide provides sample poems, songs, and possible items for session inclusion or application to the SISTA Hispanic women/Latina adaptation. The guide provides examples of the materials needed when adapting the intervention for Latinas. 
TABLE 1. Diffusion of Effective Behavioral Interventions Currently in Dissemination or Preparation for Dissemination (Partial List ${ }^{\mathrm{a}}$ )

\begin{tabular}{|c|c|c|c|c|}
\hline Citation & $\begin{array}{l}\text { Sample in } \\
\text { Original Study }\end{array}$ & $\begin{array}{l}\text { Intervention } \\
\text { Setting }\end{array}$ & $\begin{array}{l}\text { Intervention Name } \\
\text { and Summary }\end{array}$ & Outcomes \\
\hline CDC, 1999 & $\begin{array}{l}\text { Community } \\
54 \% \text { African-American, } \\
22 \% \text { White, } \\
19 \% \text { Hispanic, } 5 \% \text { Other }\end{array}$ & $\begin{array}{l}\text { Public areas, social } \\
\text { clubs, businesses, } \\
\text { community sites, } \\
\text { bars, shooting } \\
\text { galleries }\end{array}$ & $\begin{array}{l}\text { Community Promise } \\
\text { Community-level interven- } \\
\text { tion to promote progress } \\
\text { toward consistent HIV } \\
\text { prevention through } \\
\text { community mobilization } \\
\text { and distribution of small } \\
\text { media by community peer } \\
\text { advocates }\end{array}$ & $\begin{array}{l}\text { Increased consistent } \\
\text { condom use; in- } \\
\text { creased disinfecting of } \\
\text { injection equipment } \\
\end{array}$ \\
\hline $\begin{array}{l}\text { Clark et al. } \\
(2005)\end{array}$ & $\begin{array}{l}\text { Middle-school youth } \\
100 \% \text { African American } \\
\text { analytic sample }\end{array}$ & $\begin{array}{l}\text { Middle school } \\
\text { classroom }\end{array}$ & $\begin{array}{l}\text { Project AIM- Adult } \\
\text { Identity Monitoring } \\
\text { Group-level youth de- } \\
\text { velopment intervention } \\
\text { designed to reduce HIV } \\
\text { risk behaviors among } \\
\text { youth through focus on } \\
\text { positive future selves and } \\
\text { skills for avoiding risky } \\
\text { behaviors }\end{array}$ & $\begin{array}{l}\text { Increased abstinence } \\
\text { Decreased intention to } \\
\text { engage in sex }\end{array}$ \\
\hline $\begin{array}{l}\text { El-Bassel et al., } \\
\text { (2003) }\end{array}$ & $\begin{array}{l}217 \text { heterosexual couples } \\
21 \% \text { HIV+ } \\
30 \% \text { Latino }\end{array}$ & $\begin{array}{l}\text { Primary health } \\
\text { care }\end{array}$ & $\begin{array}{l}\text { CONNECT } 6 \text { weeks } \\
\text { Couples-Based Interven- } \\
\text { tion }\end{array}$ & $\begin{array}{l}\text { Frequency unprotected } \\
\text { sex acts } \\
\text { Proportion protected } \\
\text { sex acts } \\
\text { Number of sexual } \\
\text { partners }\end{array}$ \\
\hline $\begin{array}{l}\text { Kalichman et al., } \\
2001\end{array}$ & $\begin{array}{l}\text { HIV + men and women } \\
74 \% \text { African American, } \\
22 \% \text { White; } 4 \% \text { other }\end{array}$ & $\begin{array}{l}\text { AIDS services and } \\
\text { infectious disease } \\
\text { clinics }\end{array}$ & $\begin{array}{l}\text { Healthy Relationships } \\
\text { Five session small group } \\
\text { intervention focused on } \\
\text { developing skills and } \\
\text { building self-efficacy and } \\
\text { positive expectations } \\
\text { about new behaviors }\end{array}$ & $\begin{array}{l}\text { Reduced unprotected } \\
\text { anal or vaginal inter- } \\
\text { course } \\
\text { Fewer non-HIV+ sex } \\
\text { partners } \\
\text { Increased condom use } \\
\text { Increased refusal of } \\
\text { unsafe sex }\end{array}$ \\
\hline $\begin{array}{l}\text { Kamb et al. } \\
(1998)\end{array}$ & $\begin{array}{l}\text { Any person at increased } \\
\text { risk for HIV/STD } \\
19 \% \text { Latino }\end{array}$ & STD clinics & $\begin{array}{l}\text { RESPECT } \\
\text { individual-level, client- } \\
\text { focused, consisting of two }\end{array}$ & $\begin{array}{l}\text { Reported Increased } \\
\text { condom use and re- } \\
\text { duction in new STDs }\end{array}$ \\
\hline
\end{tabular}
brief interactive counsel-

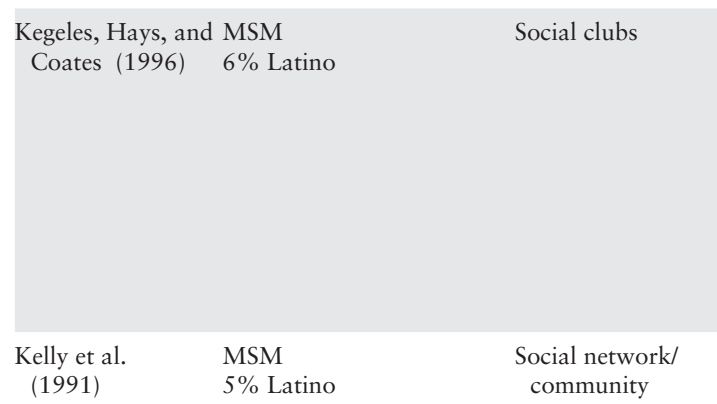

ing sessions

MPowerment

community-level interven-

tion for young MSM

Uses informal and formal outreach, discussion groups, creation of safe spaces, social opportunities, and social marketing with HIV prevention, safer sex, and risk reduction messages

POL

Community-level intervention involves identifying enlisting, and training key opinion leaders to encourage safer sexual norms and behaviors through risk-reduction conversations within their social networks

\section{Decreased rates of} unprotected anal intercourse 
TABLE 1. Diffusion of Effective Behavioral Interventions Currently in Dissemination or Preparation for Dissemination (Partial List ${ }^{\mathrm{a}}$ )

\begin{tabular}{|c|c|c|c|c|}
\hline Citation & $\begin{array}{l}\text { Sample in } \\
\text { Original Study }\end{array}$ & $\begin{array}{l}\text { Intervention } \\
\text { Setting }\end{array}$ & $\begin{array}{l}\text { Intervention Name } \\
\text { and Summary }\end{array}$ & Outcomes \\
\hline $\begin{array}{l}\text { Margolin, Avants, } \\
\text { Warburton, } \\
\text { Hawkins, \& Shi } \\
\text { (2003) }\end{array}$ & $\begin{array}{l}\text { IDU patients in methadone } \\
\text { treatment } \\
100 \% \text { HIV+ } \\
16 \% \text { Latino }\end{array}$ & $\begin{array}{l}\text { Methadone treat- } \\
\text { ment }\end{array}$ & $\begin{array}{l}\text { Holistic Health Recovery } \\
\text { Program (HHRP) an } \\
\text { HIV+ Harm Reduction } \\
\text { Program } \\
12 \text { session manual-guided } \\
\text { group-level program } \\
\text { focused on health } \\
\text { promotion and improved } \\
\text { quality of life; absti- } \\
\text { nence from illicit drug } \\
\text { use or from sexual risk } \\
\text { behaviors; reduced drug } \\
\text { use; reduced risk fo rHIV } \\
\text { transmission; improved } \\
\text { medical, psychological } \\
\text { and social functioning }\end{array}$ & $\begin{array}{l}\text { Reduced unprotected } \\
\text { penetrative sex }\end{array}$ \\
\hline $\begin{array}{l}\text { O’Donnell et al. } \\
(1998)\end{array}$ & $\begin{array}{l}\text { Male and Female STD } \\
\text { clinic patients } \\
38 \% \text { Latino }\end{array}$ & STD clinics & $\begin{array}{l}\text { VOICES/VOCES } \\
\text { Single-session, video-based } \\
\text { intervention designed to } \\
\text { increase condom use }\end{array}$ & Reduced new STI \\
\hline $\begin{array}{l}\text { Peragallo et al. } \\
\text { (2005) }\end{array}$ & $\begin{array}{l}\text { Hispanic/Latino women } \\
100 \% \text { Hispanic }(85 \% \\
\text { Mexican, } 15 \% \text { Puerto } \\
\text { Rican) } \\
100 \% \text { Female }\end{array}$ & $\begin{array}{l}\text { Community } \\
\text { agencies }\end{array}$ & $\begin{array}{l}\text { SEPA } \\
\text { six-session, culturally- } \\
\text { tailored, small-group, } \\
\text { skills building interven- } \\
\text { tion designed to prevent } \\
\text { high-risk sexual behav- } \\
\text { iors among low-income } \\
\text { women }\end{array}$ & $\begin{array}{l}\text { Reported consistent } \\
\text { condom use during } \\
\text { vaginal intercourse }\end{array}$ \\
\hline Rhodes (2000) & $\begin{array}{l}\text { Male and Female IDUs } \\
20 \% \text { Latino }\end{array}$ & $\begin{array}{l}\text { Store-front office, } \\
\text { local community } \\
\text { office, public area }\end{array}$ & $\begin{array}{l}\text { Safety counts } \\
\text { Seven-session interven- } \\
\text { tion, which includes both } \\
\text { structured and unstruc- } \\
\text { tured psycho-educational } \\
\text { activities in group and } \\
\text { individual settings. }\end{array}$ & $\begin{array}{l}\text { Reduced drug injection; } \\
\text { Reduced reduced } \\
\text { sharing works; }\end{array}$ \\
\hline $\begin{array}{l}\text { Richardson et al. } \\
(2004)\end{array}$ & $\begin{array}{l}\text { Sexually active patients } \\
\text { seeking HIV treatment } \\
100 \% \text { HIV+ } \\
>30 \% \text { Latino }\end{array}$ & HIV clinics & $\begin{array}{l}\text { Partnership for Health a } \\
\text { Gain-Framed Safer-Sex } \\
\text { Intervention }\end{array}$ & $\begin{array}{l}\text { Unprotected insertive } \\
\text { or receptive anal or } \\
\text { vaginal intercourse }\end{array}$ \\
\hline $\begin{array}{l}\text { Robles et al. } \\
(2004)\end{array}$ & $\begin{array}{l}\text { IDUs } \\
100 \% \text { Latino }\end{array}$ & $\begin{array}{l}\text { Community clinic; } \\
\text { store-front office; } \\
\text { drug treatment } \\
\text { program }\end{array}$ & $\begin{array}{l}\text { Modelo de Intervención } \\
\text { Psicomédica (MIP) } \\
\text { Psycho-medical interven- } \\
\text { tion model for injection } \\
\text { drug users based on } \\
\text { motivational interviewing } \\
\text { and case management. }\end{array}$ & $\begin{array}{l}\text { Reduced injection drug } \\
\text { use; Reduced needle } \\
\text { sharing. }\end{array}$ \\
\hline $\begin{array}{l}\text { Rotheram-Borus } \\
\text { et al. (2004) }\end{array}$ & $\begin{array}{l}\text { HIV+ adolescents and } \\
\text { young adults } \\
100 \% \text { HIV+ } \\
42 \% \text { Latino }\end{array}$ & $\begin{array}{l}\text { Community } \\
\text { agencies }\end{array}$ & $\begin{array}{l}\text { CLEAR is an individual- } \\
\text { level intervention that } \\
\text { focuses on quality of } \\
\text { life and transmission } \\
\text { risk-reduction. It can be } \\
\text { modified for Comprehen- } \\
\text { sive Risk Counseling and } \\
\text { Services. }\end{array}$ & $\begin{array}{l}\text { Reduced number of } \\
\text { HIV - partners In- } \\
\text { creased protected sex } \\
\text { acts with partners } \\
100 \% \text { condom use or } \\
\text { abstinence }\end{array}$ \\
\hline $\begin{array}{l}\text { Rotheram-Borus, } \\
\text { Gwadtz, Lee, } \\
\text { Van Rossem, \& } \\
\text { Koopman } \\
\text { et al., } 1997\end{array}$ & $\begin{array}{l}\text { Adolescents } \\
22 \% \text { Latino }\end{array}$ & $\begin{array}{l}\text { Shelters for run- } \\
\text { away adolescents }\end{array}$ & $\begin{array}{l}\text { STREET SMART group- } \\
\text { level } 10 \text { sessions to } \\
\text { mobilize and reinforce } \\
\text { positive behaviors }\end{array}$ & $\begin{array}{l}\text { Reduced number of un- } \\
\text { protected sex acts and } \\
\text { reduced substance } \\
\text { abuse }\end{array}$ \\
\hline $\begin{array}{l}\text { Rotheram-Borus } \\
\text { et al. (2001) }\end{array}$ & $\begin{array}{l}\text { HIV+ adolescents and } \\
\text { young adults } \\
100 \% \text { HIV+ } \\
37 \% \text { Latino }\end{array}$ & $\begin{array}{l}\text { Adolescent Clinical } \\
\text { clinical sites }\end{array}$ & $\begin{array}{l}\text { Together Learning Choices } \\
\text { is a transmission risk- } \\
\text { reduction and health } \\
\text { promotion intervention } \\
\text { with } 2 \text { modules: "Stay } \\
\text { Healthy" and "Act Safe". }\end{array}$ & $\begin{array}{l}\text { Reduced number of } \\
\text { sexual partners and } \\
\text { unprotected sex acts }\end{array}$ \\
\hline
\end{tabular}




\begin{tabular}{|c|c|c|c|c|}
\hline $\begin{array}{l}\text { Villarruel, Jem- } \\
\text { mott, \& Jemmott } \\
(2006)\end{array}$ & $\begin{array}{l}\text { Adolescents } \\
100 \% \text { Latino analytic } \\
\text { sample ( } 85 \% \text { Puerto } \\
\text { Rican) }\end{array}$ & $\begin{array}{l}\text { High schools and } \\
\text { community based } \\
\text { organizations }\end{array}$ & $\begin{array}{l}\text { Cuidate } \\
\text { Culturally based interven- } \\
\text { tion to reduce HIV sexual } \\
\text { risk among Latino youth. } \\
\text { Consists of six } 60 \text {-minute } \\
\text { modules delivered to } \\
\text { small, mixed-gender } \\
\text { groups }\end{array}$ & $\begin{array}{l}\text { Fewer reports of } \\
\text { sexual intercourse, } \\
\text { unprotected sexual } \\
\text { intercourse; for Span- } \\
\text { ish speakers, greater } \\
\text { proportion Propor- } \\
\text { tion of protected } \\
\text { sexual acts and more } \\
\text { likely to use condom } \\
\text { at last intercourse }\end{array}$ \\
\hline $\begin{array}{l}\text { Warner et al. } \\
(2008)\end{array}$ & $\begin{array}{l}\text { STD clinic patients } 25 \% \\
\text { Latino }\end{array}$ & STD clinics & $\begin{array}{l}\text { Safe in the City } \\
\text { Single-session, video-based } \\
\text { intervention }\end{array}$ & Reduction in new STI \\
\hline $\begin{array}{l}\text { Wilton et al. } \\
\text { (2009); Kelly, St. } \\
\text { Lawrence, Hood, } \\
\text { \& Brasfield } \\
(1989)\end{array}$ & $\begin{array}{l}\text { Young MSM } \\
17 \% \text { Latino }\end{array}$ & Community agency & $\begin{array}{l}3 \mathrm{MV} \\
\text { 7-session, group-level } \\
\text { intervention program to } \\
\text { prevent HIV and sexu- } \\
\text { ally transmitted diseases } \\
\text { among MSM who may } \\
\text { or may not identify them- } \\
\text { selves as gay }\end{array}$ & $\begin{array}{l}\text { Reduced frequency } \\
\text { of unprotected anal } \\
\text { intercourse and } \\
\text { increased their use of } \\
\text { condoms }\end{array}$ \\
\hline CDC (1999) & $\begin{array}{l}\text { Community } \\
54 \% \text { African-American, } \\
22 \% \text { White, } 19 \% \text { Hispan- } \\
\text { ic, } 5 \% \text { Other } \\
55 \% \text { Female, } 45 \% \text { Male } \\
6 \% \text { non-gay identified } \\
\text { MSM } \\
19 \% \text { Latino }\end{array}$ & $\begin{array}{l}\text { Public areas, social } \\
\text { clubs, businesses, } \\
\text { - community sites, } \\
\text { bars, shooting } \\
\text { galleries. }\end{array}$ & $\begin{array}{l}\text { Community Promise } \\
\text { Community-level interven- } \\
\text { tion to promote progress } \\
\text { toward consistent HIV } \\
\text { prevention through } \\
\text { community mobilization } \\
\text { and distribuition of small } \\
\text { media by community peer } \\
\text { advocates }\end{array}$ & $\begin{array}{l}\text { Increased consis- } \\
\text { tent condom use; } \\
\text { Increased increased } \\
\text { disinfecting of injec- } \\
\text { tion equipment }\end{array}$ \\
\hline $\begin{array}{l}\text { Wolitski et al. } \\
(2006)\end{array}$ & $\begin{array}{l}\text { Males soon to be released } \\
\text { from prison } \\
14 \% \text { Latino }\end{array}$ & $\begin{array}{l}\text { Prisons pre-release } \\
\text { and Community } \\
\text { community-based } \\
\text { organizations, } \\
\text { post- release }\end{array}$ & $\begin{array}{l}\text { START } \\
\text { 6-session individual-level } \\
\text { HIV, STD, and hepatitis } \\
\text { risk reduction interven- } \\
\text { tion for men soon to be } \\
\text { released from prison. } \\
\text { Incorporates preven- } \\
\text { tion case management, } \\
\text { motivational interview- } \\
\text { ing, and incremental risk } \\
\text { reduction }\end{array}$ & $\begin{array}{l}\text { Reduced unprotected } \\
\text { sexual intercourse }\end{array}$ \\
\hline
\end{tabular}

Note. STD - Sexually transmitted disease; MSM - men who have sex with men; IDUs - injection drug users. ${ }^{\mathrm{a} T a b l e}$ includes interventions currently in or in preparation for dissemination by Hispanic/Latino serving agencies. For a complete list of DEBIs, please see effectiveinterventions.org

Both the RAPP and 3MV interventions were adapted for use in Puerto Rico early on in the DEBI project, as agencies were in need of materials in Spanish for women and MSM. Recently, the LDT and partners formally evaluated 3MV materials. The intervention $3 \mathrm{MV}$ was recently translated and adapted in communities for both Puerto Rico and Hispanic/Latino-serving agencies in the mainland United States.

The AIM intervention, though currently in the packaging stages, is already being diffused in Los Angeles among a largely Hispanic/Latino population of youth involved in after-school programs and young male-to-female transgendered persons. Project AIM is designed to reduce the HIV risk behaviors among youth through activities based on the theory of possible selves (Markus, \& Nurius, 1986). Project AIM encourages at-risk youth to imagine a positive future and discuss how current risk behaviors can be a barrier to a successful adulthood. Owing to its efficacy and unique approach of HIV prevention without direct discussion of sexual behavior, there has been keen interest from Hispanic/Latino serving agencies and communities. 
The Safety Counts intervention, originally targeting drug users of all ethnic backgrounds, was recently adapted for Hispanic/Latino migrant farm worker IDUs. Formative evaluation procedures were employed by the Border Health Foundation in Yuma County, Arizona, and a training protocol is in development in collaboration with the Safety Counts Diffusion Team, the original researcher, and the Border Health Foundation (Anderson, 2006).

DEBI packages that have been developed in Spanish in collaboration with the CDC or are in the process of being translated include VOICES/VOCES, Partnership for Health, Connect, MIP, Community Promise, 3MV, RAPP, RESPECT, Popular Opinion Leader (POL), Street Smart, HHRP, and Healthy Relationships. Whether developed by the original research teams, DEBI diffusion team partners (internal and external to the $\mathrm{CDC}$ ), or government contractors, most intervention materials developed in collaboration with the CDC are reviewed by a minimum of three members of the Hispanic/Latino Diffusion Team with technical backgrounds in health education training and behavioral science, in addition to Spanish bilingual skills. In addition, three DEBI Diffusion Teams-Safety Counts, MIP, and Community Promisehave their own Hispanic/Latino cultural and technical expertise and work in the packaging and adaptation of EBIs in collaboration with the LDT (J. Andía, personal communication, July 8, 2009). Review of translations is guided by following English materials and reviewing to ensure fidelity in the Spanish version to the original intent of the intervention. Intervention dissemination materials include a glossary of Spanish and English terms for the specific intervention. The final translated materials have been reviewed by a materials review panel comprising persons representative of the target populations. The panel reviews the materials for appropriate linguistic translation for the specific Hispanic/Latino population addressed, the clarity of the materials, and the cultural appropriateness of the materials. In some cases, CBOs funded to implement evidence-based interventions have created their own Spanish linguistic and cultural translations. These products are often obtained by CDC project officers and reviewed by the LDT. These products are valuable community produced assets that, once reviewed for fidelity to the science, can be used by other community based organizations serving Hispanic/Latino populations. Spanish language versions of the SISTA, RAPP, 3MV, and Mpowerment interventions are known to have been developed in this manner and used in community agencies. Spanish language trainings supported by the CDC have also been prepared and delivered for the following interventions: Safety Counts, Community Promise, RESPECT, Healthy Relationships, MIP, and 3MV.

\section{DISSEMINATION CHALLENGES AND SUCCESS}

From the beginning of the DEBI Project, there has been a challenge to meet the needs of the diverse Hispanic/Latino populations at risk for HIV/AIDS. The challenges of dissemination of DEBIs, including implementation, have been documented by agencies to include: goodness of fit with community served; retention of participants; staff turnover; and agency capacity building (Veniegas, Kao, Rosales, \& Arellanes, 2009).

It is well documented that new technologies often are met with initial resistance, and uptake entails engaging key stakeholders and gaining support from agency insiders and the community. The perception of availability of few Hispanic/Latinotailored, English-only materials further reinforces that resistance.

Although many interventions disseminated through the DEBI Project included Hispanics/Latinos in the original research sample group, few were specifically de- 
signed for Hispanics/Latinos. As a result, some agencies perceived this paucity of Hispanic/Latino specific interventions as a barrier to their HIV prevention work. However, several interventions have been developed for Hispanic/Latino populations (Herbst et al., 2007), and interventions do not need to be specifically designed for Hispanics/Latinos or have a majority of Hispanics/Latinos in the sample population to be effective. There is a challenge in imparting to front-line prevention providers information that the behavioral interventions target risk behaviors and risk determinants for change, not ethnicity. Another basic challenge for LDT has been in prioritization of activities, including determined which interventions needed to be adapted or translated first and securing funding for the adaptation and translation process.

Agency capacity building is another challenge to the diffusion of evidence-based intervention into Hispanic/Latino communities. These include matching the best intervention to the capacity of the grantees and target populations served. For many agencies, even if the agency had the capacity to implement a selected intervention and the intervention addressed the risk determinants of its target population, materials available only in English needed to be translated to Spanish before implementation could begin. This delayed implementation for some agencies while materials were prepared in Spanish and perhaps influenced their decision on selection of another, already translated intervention for others. The observation that a Latino-serving agency will select an intervention because it already has a Spanish translation is of concern because the intervention selection was based on availability of Spanish materials rather than a thoughtful selection of an intervention that addressed the risk determinants displayed by the target population.

There have been noteworthy successes. Successful outcomes included concentrated efforts in adapting materials for subgroups of Hispanics/Latinos and support for more materials in Spanish to better serve the needs of monolingual partners, including most agencies in Puerto Rico. Offering Spanish language translations of evidence-based interventions provides not only a product with high utility but also conveys a message to underserved communities that the CDC is trying to reach them with culturally and linguistically appropriate materials. For example, the CDC originally translated the Safety Counts intervention from English into Spanish. Using a model of committee peer reviewers (Cortes et al., 2007), a group of bilingual CBA trainers from multiple regions in the United States (Latino Commission on AIDS, BHF, Cicatelli, Inc., Puerto Rican Organization for Community Education and Economic Development, Inc. [PROCEED], and AIDS Project Los Angeles [APLA]), translated, reviewed, and piloted training protocols in multiple regions in the nation (e.g., Los Angeles, New York, and Florida), including Puerto Rico. The translated package was reviewed by Safety Counts diffusion team experts to produce a general Spanish version of the intervention (J. Andía, personal communication, February 2, 2006). Subsequently, five Safety Counts trainings have been conducted in Spanish. Likewise, the Spanish language adaptation of Community PROMISE (Peers Reaching Out and Modeling Intervention Strategies for HIV/AIDS Risk Reduction in Their Community) intervention and training materials, was developed in collaboration with CBA providers, Prevention Training Centers, (PTCs), and CDC staff. Since 2003, more than 15 Community PROMISE trainings have been conducted for monolingual Spanish speakers, resulting in approximately 300 participants.

The MIP intervention (Robles et al., 2004), originally developed in Puerto Rico with IDUs, has been packaged by the CDC for use with IDUs of multiethnic backgrounds and is available in both English and Spanish. Working closely with the 
original investigators, a CBA provider (PROCEED), and CDC behavioral scientists, a translation exchange methodology was used that incorporated the programmatic experiences from the implementation process (Pemberton et al., this issue). Diffused since 2008, the MIP intervention is an example of an evidence-based intervention that although originally tested with Hispanics/Latinos, targets the risk determinants (e.g., self-efficacy, social support, and role induction) and risk factors (e.g., access to health services and access to drug treatment programs) considered universal and not specific to any race or ethnicity (R. Robles personal communication, August 2007).

Further successes have been documented by agencies serving the needs of Hispanics/Latinos at risk for HIV/AIDS. A CBA provider, Latino Commission on AIDS, has developed the Customized, Holistic, Analytical, Network-building, Grassroots, Evaluatory (CHANGE) model for effective capacity-building assistance in the DEBI diffusion project (Vega, this issue). Additionally, the capacity-building provider, PROCEED, documents success in the diffusion of the MIP intervention, highlighting the importance of technical assistance and trainer mentoring to enhance training capacity (Pemberton et al., this issue).

Although there have been more challenges and successes during the first 7 years of DEBI, the aforementioned highlight some of the experience of the agencies, and LDT in working to meet the needs of Hispanic/Latino populations at risk for HIV/ AIDS in the United States and Puerto Rico.

\section{FUTURE DIRECTION OF DEBIS AND HISPANIC/LATINOS}

With the inventory of EBIs growing annually (Lyles et al., 2009), more intervention options exist for targeting HIV/AIDS among all groups, including at-risk Hispanics/Latinos. The DEBI Project intends to continue to involve Hispanic/Latino communities, HIV prevention partners, implementing agencies, and prevention training centers in the diffusion process. With the development of adaptation guidelines, it may be possible to provide culturally and linguistically appropriate interventions for numerous at-risk populations. The LDT diffusion plans include support for additional Spanish translations of DEBI intervention packages and training materials. In addition, as new evidence-based interventions are identified that specifically take into consideration cultural norms and linguistic needs of Hispanic/Latino populations, there are potential opportunities for a better intervention match for agencies serving Hispanics/Latinos at risk for HIV/AIDS.

The DEBI Project continues to evolve and will likely continue to face challenges as more interventions are disseminated. The LDT is committed to ensure that culturally and linguistically appropriate materials and trainings are available to respond to the growing HIV prevention needs of Hispanics/Latinos in the United States, including Puerto Rico.

Interventions that are intended to reach Hispanic/Latino populations will have to be varied and target the full spectrum of behaviors involved in transmission of HIV.

There are still many areas of improvement in regard to addressing prevention for at-risk Hispanics/Latinos and HIV/AIDS. These improvements include service integration into evidence-based prevention so that underserved communities can be offered screenings for STDs, tuberculosis, hepatitis, domestic violence, mental health, and substance-abuse treatment screening. It is noteworthy that MIP, the first intervention fully developed in Spanish by Spanish-speaking behavioral scientists and originally designed specifically for Spanish-speaking drug users, uses a casemanagement strategy that is appropriate for screening for multiple health conditions 
and referral for a range of services. If the needs of Hispanic/Latino communities around HIV prevention are to be fully addressed, the interventions delivered in Hispanic/Latino communities must be holistic and address service integration.

Through appropriate material development and translation, careful CBA, and the eight steps for diffusion that include assessment of the community targeted, quality assurance, and technical assistance, it is possible to create success in diffusion of evidence-based prevention in Latino communities as referenced in this paper. Because of the evolving needs of communities, including Latinos at risk for HIV, it is expected that the evidence-based interventions disseminated through the DEBI Project will have to be adapted and the inventory of interventions will also grow to reflect the changing needs. Adaptation should be based on formative evaluation procedures with careful monitoring to ensure fidelity to the original intent of the intervention's theoretical constructs. With the collaboration of capacity-building providers, prevention training centers, health departments, and community based agencies, the DEBI project and the LDT will continue to work to help meet the needs of Hispanic/Latino communities at risk for HIV/AIDS.

\section{REFERENCES}

American Psychological Association (APA) Resource guide for adapting SISTA for Latinas. Editors: Phields, Anderson, Collins \& Stallworth. 2008.

Anderson, C.A. (2006, August). Final report to the Centers for Disease Control and Prevention on adapting safety counts for migrant workers who use drugs. Retrieved July 8, 2009, from http://www.borderhealthfoundation. org/SC_Migrant_Results.pdf

Andía, J. Centers for Disease Control and Prevention. Personal Communication., February 2, 2006.

Andía, J. Centers for Disease Control and Prevention. Personal Communication. July 8 , 2009.

Centers for Disease Control and Prevention. (1999). Community-level HIV intervention in five cities: final outcome data from the AIDS Community demonstration projects. American Journal of Public Health, 89(3), 336-345.

Centers for Disease Control and Prevention. (2006). Project officer assessment. GA: Author, Division of HIV/AIDS Prevention.

Centers for Disease Control and Prevention. (2007a). Capacity building branch report, GA: Author, Division of HIV/AIDS Prevention.

Chen, S.Y., Gibson, S., Katz, M.H., Klausner, J.D., Dilley, J.W., Schwarcz, S.K., et al. (2002). Continuing increases in sexual risk behavior and sexually transmitted diseases among men who have sex with men, San Francisco,
1999-2001. American Journal of Public Health, 92, 1387-1388.

Clark, L., Miller, K., Nagy, S., Avery, J., Roth, D., Liddon, N., et al. (2005). Adult identity mentoring: Reducing sexual risk for African-American seventh grade students. Journal of Adolescent Health, 37, 337.e1-337. e10.

Collins, C., Harshbarger, C., Sawyer, R., \& Hamdallah, M. (2006). The Diffusion of Effective Behavioral Interventions Project: Development, implementation, and lessons learned. AIDS Education and Prevention, 18 (Suppl. A), 5-20.

Collins, C., Phields, M., \& Duncan, T. (2007). An agency capacity model to facilitate implementation of evidence-based behavioral interventions by community-based organizations. Journal of Public Health Management Practice, (Suppl. 13), S16-S23.

Cortés, D.E., Genera., M., Canino, G., AguilarGaxiola, S., Febo, V., Magaña, C. et al., (2007). Translation and cultural adaptation of a mental health outcome measure: The BASIS-R@. Culture, Medicine, and Psychiatry, 31, 25-49.

Duffus, W.A., Barragan, L., Metsch, L. Krawczyk, C.S., Laughlin, A.M., Gardner, L.I., et al. (2003) Effect of physician specialty on counseling practices and medical referral pattern among physicians caring for disadvantaged human immunodeficiency virusinfected populations. Clinical Infectious Disease, 36, 1577-1584. 
El-Bassel, N., Witte, S., Gilbert, L., Wu E., Chang, M., Hill, J., and Steinglass, P. (2003). The efficacy of a relationship-based HIVSTD prevention program for heterosexual couples. American Journal of Public Health 93(6), 963-969

El-Bassel, N., Witte, S.S., Gilbert, L., Wu, E., Chang, M., Hill, J., et al. (2005). Long term effects of an HIV/STI sexual risk reduction intervention for heterosexual couples. AIDS and Behavior, 9(1), 1-13.

Harshbarger, C., Simmons, G., Coelho, H., Sloop, K., \& Collins, C. (2006). An empirical assessment of implementation, adaptation, and tailoring: The evaluation of CDC's National Diffusion of VOICES/VOCES. AIDS Education and Prevention, 18(4, Suppl. A), 184-197.

Herbst, J.H., Kay, L.S., Passin, W.F., Lyles, C.M., Crepaz, N., \& Marín, B.V. (2007). A systematic review and meta-analysis of behavioral interventions to reduce HIV risk behaviors of Hispanics in the United States and Puerto Rico. AIDS and Behavior Volume, 11, 1, 25

Kalichman, S.C., Rompa, D., Cage, M., DiFonzo, K., Simpson, D., Austin, J., et al (2001). Effectiveness of an intervention to reduce HIV transmission risks in HIV-positive people. American Journal of Preventive Medicine, $21,84-94$

Kamb, M.L., Fishbein, M., Douglas, J.M., Rhodes, F., Rogers, J., Bolan, G., Zenilman, J., Hoxworth, T., Malotte, K., Iatesta, M., Kent, C., Lentz, A., Graziano, S., Beyers, R.H., Peterman, T.A., for the Project RESPECT Study Group. (1998). Efficacy of Risk-Reduction Counseling to Prevent Human Immunodeficiency Virus and Sexually Transmitted Diseases: A Randomized Controlled Trial. Journal of the American Medical Association, 280, 1161-67.

Kegeles, S.M., Hays, R.B., Coates, T.J. (1996). The Mpowerment Project: A Community-level HIV Prevention Intervention for Young Gay Men. American Journal of Public Health, 86 (8), $1129-1136$.

Kelly, J.A., St. Lawrence, J.S., Hood, H.V., Brasfield, T.L. (1989). Behavioral intervention to reduce AIDS risk activities. Journal of Consulting and Clinical Psychology, 57(1), 60-67.

Kelly, J.A., Somlai, A.M., DiFranceisco, W.J., Otto-Salaj, L.L., McAuliffe, T.L., Hackl, K.L., et al. (2000). Bridging the gap between the science and service of HIV prevention: Transferring effective research-based HIV prevention interventions to community AIDS service providers, American Journal of Public Health, 90(7), 1082-1088.

Kelly, J.A., St. Lawrence, J.S., Diaz, Y.E., Stevenson, L.Y., Hauth, A.C., Brasfield, T.L.
(1991). HIV risk behavior reduction following intervention with key opinion leaders of population: An experimental analysis. American Journal of Public Health, 81(2), 168-171.

Lauby, J.L., Smith, P.J., Stark, M., Person, B., \& Adams, J. (2000). A community-level HIV prevention intervention for inner-city women: Results of the women and infants demonstration projects. American Journal of Public Health, 90(2), 216-222.

Margolin, A., Avants, S.K., Warburton, L.A., Hawkins, A., \& Shi, J. (2000). A randomized clinical trial of a manual-guided risk reduction intervention for HIV-positive injection drug users. Health Psychology, 222(2), 223-228.

Markus, H., \& Nurius, P. (1986). Possible selves. American Psychologist, 4, 654-969.

Peragallo, N., DeForge, D., O'Campo, P., Lee, S. M., Kim, Y. J., Cianelli, R., et al. (2005). A randomized clinical trial of an HIV-riskreduction intervention among low-income Latina women. Nursing Research, 54, 108-118.

Rhodes, F., Wood, M.M., \& Hershberger, S.L. (2000). A cognitive-behavioral intervention to reduce HIV risks among active drug users: Efficacy study. In Staying negative in a positive world: HIV prevention strategies that work (pp. 113-124). Sacramento: California Department of Health Services, Office of AIDS.

Richardson, J.L., Milam, J., McCutchan, A., Stoyanoff, S., Bolan, R., Weiss, J., et al. (2004). Effect of brief provider safer-sex counseling of HIV-1 positive patients: A multi-clinic assessment. AIDS, 18, 1179-1186.

Robles, R. R., Reyes, J.C., Colón, H.M., Sahai, H., Marrero, C.A., Matos, T.D., et al., (2004). Effects of combined counseling and case Management to reduce HIV risk behaviors among Hispanic drug injectors in Puerto Rico: A randomized controlled study. Journal of Substance Abuse Treatment, 27, 145-152.

Rotheram-Borus, M.J., Song, J., Gwadz, M., Lee, M., Van Rossem, R., Koopman, C. (1993). Reductions in HIV Risk Among Runaway Youth. Prevention Science, 4(3), 173-180.

Rotheram-Borus, M.S., Lee, M.B., Murphy, D.A., et al. (2001). Efficacy of a prevention intervention for youths living with HIV. American Journal of Public Health, 91, 400-405.

Rotheram-Borus, M,J., Swendeman, D., Comulada, W.S., Weiss, R.E., Lee, M. \& Lightfoot, M. (2004) Prevention for substance-using HIV-positive young people: telephone and in-person delivery. Journal of Acquired Immune Deficiency Syndromes, 37 (Suppl.), S68-S77. 
Stanton, B., Cole, M., Galbraith, J., Li, X., Pendleton, S., Cottrell, L. (2004). Randomized trial of a parent intervention: Parents can make a difference in long-term adolescent risk behaviors, perceptions, and knowledge. Archives of Pediatric Adolescent Medicine, 158, 947-955.

Veniegas, R.C., Kao, U.H., Rosales, R., \& Arellanes, M. (2008). HIV technology transfer: Challenges and strategies in the real world. American Journal of Public Health, 99(Suppl. 1), S24-S1300.

Villarruel, A. M., Jemmott, J. B., \& Jemmott, L. S. (2006). A randomized controlled trial testing an HIV prevention intervention for Latino youth. Archives of Pediatric Adolescent Medicine, 160, 1-6.

Warner, L., Klausner, J.D., Rietmeijer, C.A., Malotte, C.K., O’Donnell, L., Margolis, A.D., Greenwood, G.L., Richardson, D., Vrungos, S., O’Donnell, C.R., and Borkowf, C.B., for the Safe in the City Study Group (2008). Effect of a Brief Video Intervention on Incident Infection among Patients Attending Sexually Transmitted Disease Clinics. PLoS Medicine 5(6), e135.

Wilton, L., Herbst, J.H., Coury-Doniger, P., Painter, T.M., English, G., Alvarez, M.E., Scahill, M., Roberson, M.A., Lucas, B., Johnson, W.D., Carey, J.W.(2009). Efficacy of an HIV/STI Prevention Intervention for Black Men Who Have Sex with Men: Findings from the Many Men, Many Voices (3MV) Project. AIDS Behavior, 13(3), 532-544.

Wolitski, R. J., \& The Project START study group. (2006). Relative efficacy of a multisession sexual risk reduction intervention for young men released from prison in 4 states. American Journal of Public Health, 96, 1845-1861. 